\title{
OPEN Mechanisms of halosulfuron methyl pesticide biosorption onto neem seeds powder
}

\author{
Atta ul Haq ${ }^{1 凶}$, Muhammad Saeed ${ }^{1}$, Muhammad Usman ${ }^{1}$, Ameer Fawad Zahoor ${ }^{1}$, \\ Muhammad Naveed Anjum ${ }^{2}$, Tahir Maqbool ${ }^{1}$, Shazia Naheed ${ }^{1}$ \& Muhammad Kashif ${ }^{1}$
}

The current investigation was designed to remove halosulfuron methyl from aqueous media by means of neem seed powder (NSP) in batch modes. Characterizations of NSP were carried out by using EDX, SEM, FTIR, point of zero charge and surface analysis. Optimum operation conditions were scrutinized by studying the influence of different factors like solution $\mathrm{pH}$, dose of NSP, contact time, initial halosulfuron methyl concentration and temperature. Result indicates the dependency of the removal of halosulfuron methyl on solution $\mathrm{pH}$ and maximal removal (54\%) was achieved in acidic medium (i.e. $\mathrm{pH}$ 3.0). To identify the chemical surface of NSP, point of zero charge of NSP was determined and was found to be 6.5 which imply that the surface of NSP is positively charged below pH 6.6 and favored the anionic sorption. Kinetics of halosulfuron methyl were demonstrated well by pseudo second order due to highest $R^{2}(0.99)$ owing to the nearness between experimental and calculated sorption capacities. Isotherm results imply that Langmuir was found to the principal model to explain the removal of halosulfuron methyl and maximum monolayer sorption capacity was determined to be $200 \mathrm{mg} \mathrm{g}^{-1}$. Thermodynamic parameters like $\Delta \mathrm{H}^{\circ}, \Delta \mathrm{G}^{\circ}$ and $\Delta \mathrm{S}^{\circ}$ were calculated from van't Hoff plot and were found negative which suggest that removal of halosulfuron methyl is exothermic and spontaneous at low temperature. These outcomes insinuate that neem seed power may be a valuable, inexpensive and ecofriendly biosorbent for the removal of pesticides.

Globalization as well as huge population pressure makes the pesticides as essential chemical agents for high quality food production. Pesticides have been identified in ground water which considered as primary fountain of drinking water worldwide. Therefore, the existence of pesticides water is of serious concern to authorities, society and potable water production agencies ${ }^{1}$. European Community Drinking Water Directive recommended an amount of $0.1 \mu \mathrm{g} \mathrm{L}^{-1}$ pesticide in drinking water. The presence of excess amounts of pesticides are highly toxic and cause various health problems like endocrine malfunction, interaction with androgen and estrogen receptors, and affect the role of thyroid whilst long-term effects of pesticides are not identified ${ }^{2}$.

Halosulfuron-methyl [methyl 3-chloro-5-(4,6-diethoxypyrimidi,-2-ylcarbamoylsulfamoyl)-1-methylpyrazole-4-carboxylate] is belong to sulfonylurea group of herbicide widely used throughout the world to control post-emergence broadleaf weed, sedge and grasses present in crops and vegetables ${ }^{3}$. The extensive usage of halosulfuron-methyl has caused the contamination of water of lakes and rivers through surface runoff and rain $^{4}$. There are many traditional methods to treat wastewater containing pesticides such as ultraviolet oxidation, membrane techniques, chemical precipitation, ion exchange, electro dialysis and chemical coagulation photocatalysis ${ }^{5-7}$. However, due to serious demerits and limitations of these methods like high operative cost, low efficiency for diluted wastewaters and generation of hazardous wastes make them unsuitable for the removal pesticides from water ${ }^{8-10}$. Therefore, it is needed to investigate new methods and techniques for sequestration of pesticides present in water which are efficiently and effectively safeguard the ecosystem and our life ${ }^{11}$. Adsorption is considered as a promising alternative method to remove pesticides and other contaminants from wastewater owing to its eco-friendly, simplicity and inexpensive $\mathrm{e}^{12-14}$. Sequestration of pollutants using biological materials by physiochemical process from dilute aqueous solution is known as biosorption ${ }^{6}$. A variety of biological materials have been used to remove various pollutants like raw plants, industrial waste, macroalgae, agricultural residues, sludge, animal materials etc. ${ }^{15-19}$. However, agro-based and forestry originating materials such as cork waste $^{20}$, Marula seed husk ${ }^{21}$, olive tree pruning ${ }^{22}$, Phytolacca americana biomass ${ }^{19}$, maize stover ${ }^{23}$, cedar leaf ${ }^{24}$,

${ }^{1}$ Department of Chemistry, Government College University Faisalabad, Faisalabad, Pakistan. ${ }^{2}$ Department of Applied Chemistry, Government College University Faisalabad, Faisalabad, Pakistan. ${ }^{\square}$ email: attaulhaq@ gcuf.edu.pk 
peanut shells ${ }^{25}$ etc. have been extensively used recently for wastewater treatment. Neem (Azadirachta indica) belongs to Meliaceae family and mostly present in semitropical and tropical regions of the world such as Pakistan, Nepal, Bangladesh and India. Each part of the neem tree such as root, leaves, bark and seed are used in various medicines. Seeds of the neem can also be used as antiviral, antifungal and antiseptic agent. It has been predicted that fourteen million trees are available only in India which produces approximately 400,000 tones of neem seeds per year. A single neem tree of 15 years old may produces up to $20 \mathrm{~kg}$ fruit or $2 \mathrm{~kg}$ neem seeds. The neem seed consists of approximately $40-45 \%$ oil while the residual part is the cellular matrix ${ }^{26}$. According to literature different parts of neem tree like leaves, bark and husk have been investigated as biosorbent for heavy metals and dyes ${ }^{27-37}$. However, according to our knowledge seeds of the neem have not been used for the removal of pesticides. The aforementioned reasons and abundant availability of the neem seeds prompted us to utilize neem seeds for treatment of wastewater containing halosulfuron-methyl.

\section{Materials and methods}

Chemicals. All chemicals utilized in the current study were of analytical grade purity and were purchased from Merck. In the present study hydrochloric acid, sodium hydroxide, boric acid, phosphoric acid, nitric acid, and acetic acid were used without any further purification. Halosulfuron methyl (purity 75\%) was purchased from local market in Faisalabad, Pakistan.

Halosulfuron methyl $\left(\mathrm{C}_{13} \mathrm{H}_{15} \mathrm{ClN}_{6} \mathrm{O}_{7} \mathrm{~S}\right)$ is belong to sulfonylurea group of herbicide widely used to control post-emergence broadleaf weed, sedge and grasses in crops and vegetables. It is a white colored powder and soluble in water at $1650 \mathrm{mg} \mathrm{L}^{-1}$. It is stable under normal handling and storage conditions. The chemical structure

of halosulfuron methyl is given below:<smiles>COC(=O)c1c(Cl)nn(C)c1S(=O)(=O)NC(=O)Nc1nc(OC)cc(OC)n1</smiles>

Instruments. In the present study different instruments have been used for their respective purposes such as analytical balance (Sartorius-GC 2012 Germany) was used for weighing of the materials. Electrical grinder (Frtsch-Pulverisette 2 of Japan) was used to grind the materials while orbital shaker was used for shaking of biosorbent and pesticide solution. Electrical oven (Memmert Celsius 2005) and pH meter (WTW-Inolab 720 Series) were used for heating of biosorbent and determination of $\mathrm{pH}$ of solution respectively. The concentrations of the pesticide before and after biosorption studies were determined by the help of UV/Vis spectrophotometer. The scanning electron microscope (SEM-Model-JSM-5910, Japan JEOL) was used to study the morphology of biosorbent while elemental composition of the biosorbent was studied with Energy Dispersive X-ray (EDXINCA 200 Oxford Instruments UK). To study the functional groups of biosorbent Fourier Transform Infrared spectrometer (Bruker ALPHA) was used while Surface Area Pore Size Analyzer (Model NOVA2200e, Quantachrome, USA) was used to study the surface analysis of biosorbent.

Preparation of standard solution of halosulfuron methyl. Halosulfuron methyl solution (200 mg $\left.\mathrm{L}^{-1}\right)$ was initially prepared in acetone $(0.1 \% \mathrm{v} / \mathrm{v})$ by dissolving appropriate quantity of commercial (75\%) halosulfuron methyl and dilute working solutions were then prepared in distilled water using dilution formula.

Preparation of biosorbent. A sufficient amount of the neem seeds (Azadirachta indica) were collected from Faisalabad city. The seeds were then completely washed with tap water and lastly washed with distilled water. Then seeds were kept in daylight for 2 weeks and ground with the help of electrical grinder. The grinded materials were then passed through sieve of mesh size $355 \mu \mathrm{m}$. These materials were transferred in a beaker containing sufficient distilled water and finally kept overnight. Supernatant of beaker was decanted many times, then filtered and washed with distilled water numerous times. Ultimately, the materials were then transferred into a china dish and dried in oven at $120^{\circ} \mathrm{C}$. After drying, materials were collected in a bottle for next research work.

Determination of point of zero charge (pHzpc). Point of zero charge of NSP was determined by following salt addition method. A particular amount of NSP $(100 \mathrm{mg})$ was added to $95 \mathrm{~mL}$ of $\mathrm{NaCl}(0.01 \mathrm{M})$ in beakers and the $\mathrm{pH}$ of the suspension was adjusted in the range of 2.0 to 10.0 with the help of $1.0 \mathrm{~N} \mathrm{HCl}$ and 1.0 $\mathrm{NaOH}$. The mixture was kept in water shaker bath for $6 \mathrm{~h}$ at ambient temperature. After $6 \mathrm{~h}$ of equilibration the final $\mathrm{pH}$ of the suspension was determined and plotted the difference (final $\mathrm{pH}-$ initial $\mathrm{pH}$ ) against the initial $\mathrm{pH}$. Point of zero charge was obtained at the intersection of initial $\mathrm{pH}$ with difference of $\mathrm{pH}$ (final $\mathrm{pH}-$ initial $\mathrm{pH})$.

Procedure for removal of halosulfuron methyl. The sorption experiments of Halosulfuron methyl using NSP were performed in batch system. The experiment was performed in $250 \mathrm{~mL}$ titration flask by incorporating a desirable quantity of NSP with $30 \mathrm{~mL}$ of halosulfuron methyl solution of particular concentration $\left(33.33 \mathrm{mg} \mathrm{L}^{-1}\right)$ at $30^{\circ} \mathrm{C}$. Mixture in flasks was then agitated for desirable interval of time at a fixed speed (150 revolutions per minute) in an orbital shaker. The mixture was then filtered and the concentration of halosulfuron methyl after sorption was determined at $\max =240 \mathrm{~nm}$ by means of Ultraviolet/Visible spectrophotometer. The 

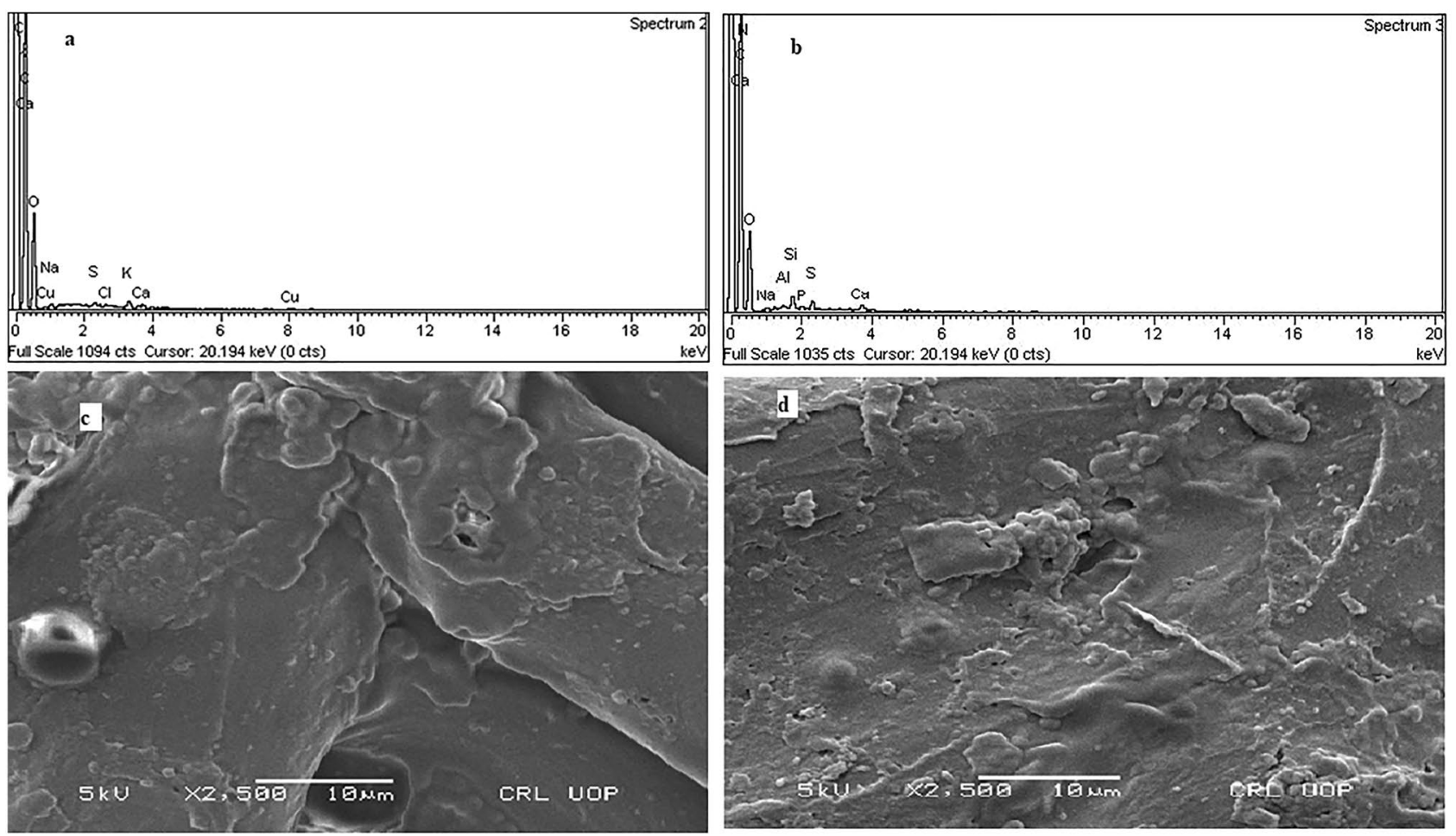

Figure 1. EDX of the NSP before removal of Halosulfuron methyl (a) EDX of the NSP after removal of Halosulfuron methyl (b) SEM of NSP before removal of Halosulfuron methyl (c) SEM of NSP after removal of Halosulfuron methyl (d).

dependency removal of halosulfuron methyl on $\mathrm{pH}$ was studied by adjusting $\mathrm{pH}$ of flask contents in ranging of 3 to 10 with Britton Robinson buffer solution (NSP $0.01 \mathrm{~g}$, halosulfuron methyl concentration $33.33 \mathrm{mg} \mathrm{L}^{-1}$ and stirring time $30 \mathrm{~min}$ ) at $30^{\circ} \mathrm{C}$. The impact of dosage of sorbent was studied by changing amount of NSP in the ranging of 0.01 to 0.08 (gram) with particular concentration of halosulfuron methyl $\left(33.33 \mathrm{mg} \mathrm{L}^{-1}\right)$ at $30^{\circ} \mathrm{C}$ and agitated for $30 \mathrm{~min}$. The influence of contact time and kinetics of the sorption process were scrutinized by taking adequate concentration of halosulfuron methyl $\left(33.33 \mathrm{mg} \mathrm{L}^{-1}\right)$ and particular amount of NSP $(0.01 \mathrm{~g})$ at $30{ }^{\circ} \mathrm{C}$ and agitated for a time of contact ranging for 10 to $70 \mathrm{~min}$. The influence of halosulfuron methyl initial concentration and isotherms were scrutinized by changing concentration of halosulfuron methyl from 33.33 to $133.33 \mathrm{mg} \mathrm{L}^{-1}$ with particular quantity of NSP $(0.01 \mathrm{~g})$ and stirring time $(30 \mathrm{~min})$ at $30^{\circ} \mathrm{C}$. The influence of temperature on removal of halosulfuron methyl was investigated in ranging of 30 to $80{ }^{\circ} \mathrm{C}$ while the keeping constant $\mathrm{pH}(3)$, time for agitation $(30 \mathrm{~min})$, amount of NSP $(0.01 \mathrm{~g})$ and initial concentration of halosulfuron methyl (33.33 $\left.\mathrm{mg} \mathrm{L}^{-1}\right)$.

To calculate the quantity of halosulfuron methyl adsorbed per unit weight of NSP $\left(\mathrm{q}_{\mathrm{t}}\right)$ at a particular time $(\mathrm{t})$ and percentage removal, following formulae were used:

$$
\begin{gathered}
q_{t}=\frac{v}{m}\left[C_{o}-C_{t}\right] \\
\operatorname{Removal}(\%)=\left[\frac{C_{O}-C_{t}}{C_{o}}\right] \times
\end{gathered}
$$

In these formulas $\mathrm{C}_{\mathrm{o}}$ and $\mathrm{C}_{\mathrm{t}}$ express the initial concentration and final concentration $\left(\mathrm{mg} \mathrm{L}^{-1}\right)$ of halosulfuron methyl, ' $m$ ' denotes the dosage of NSP (gram) and ' $\mathrm{V}$ ' expresses volume (mL) of halosulfuron methyl solution.

Regeneration study. The regeneration of contaminant-loaded biosorbent is sometime required for further biosorption study. Hence, recycling of the halosulfuron methyl-loaded NSP was conducted with different molar solutions of $\mathrm{NaOH}(1.0 \mathrm{M}, 0.1 \mathrm{M}$ and $0.01 \mathrm{M})$ because the removal of halosulfuron methyl is the minimum at higher $\mathrm{pH}$. For this purpose, $1.0 \mathrm{~g}$ of halosulfuron methyl-loaded NSP was transferred in separate beakers and $50 \mathrm{~mL}$ of $\mathrm{NaOH}$ solution of different concentrations were in each beaker. The contents were stirred in an orbital shaker for about $1 \mathrm{~h}$. The mixture was then filtered and the concentration of halosulfuron methyl after desorption was determined at $\max =240 \mathrm{~nm}$ by means of Ultraviolet/Visible spectrophotometer. 

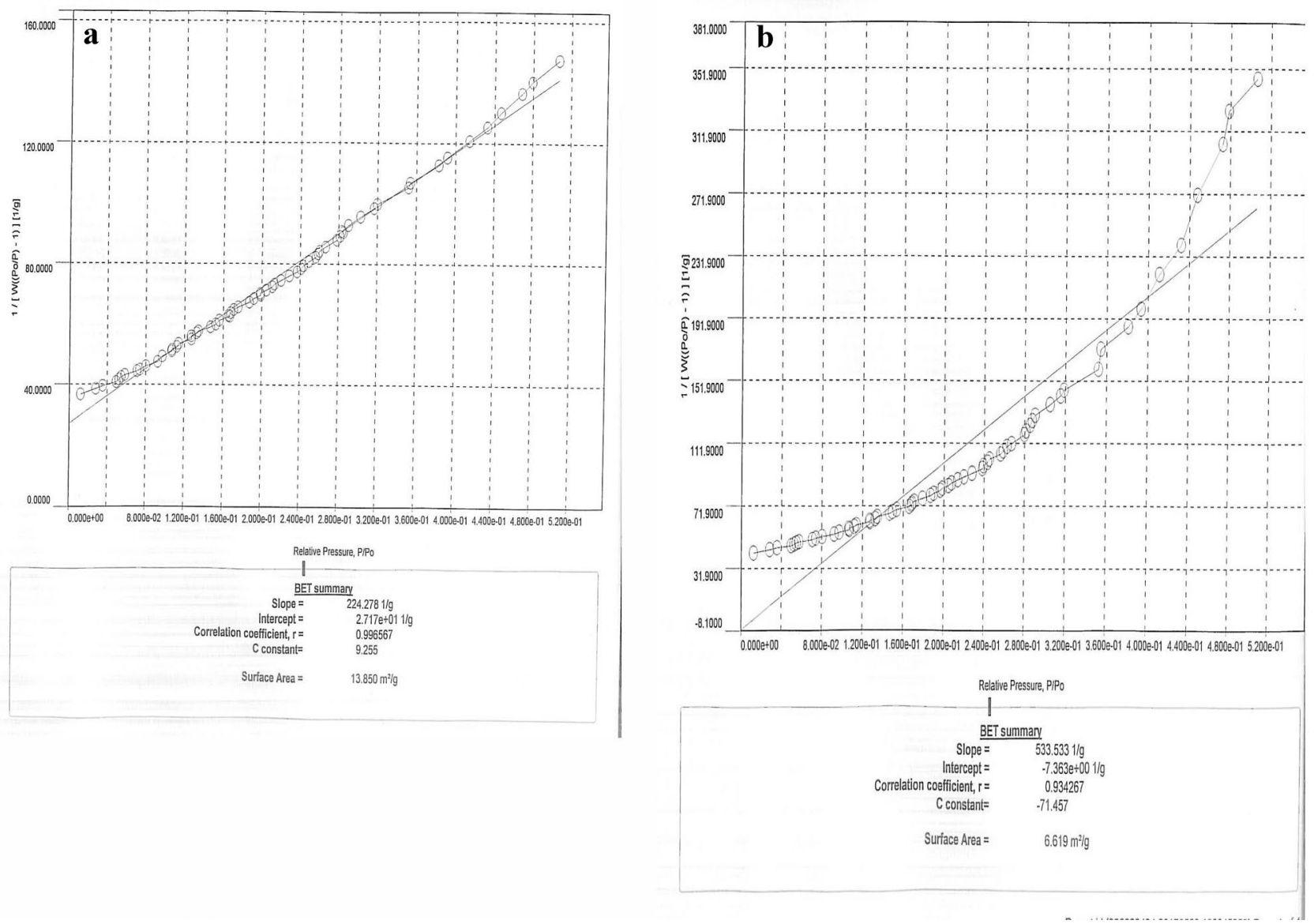

Figure 2. Nitrogen adsorption-desorption isotherm of NSP (a) before and (b) after biosorption of halosulfuron methyl.

\section{Results and discussion}

Characterizations of NSP. Neem seed powder (NSP) was characterized by EDX, SEM, surface area analysis and point of zero charge before and after removal of Halosulfuron methyl to confirm of removal of halosulfuron methyl from water media.

EDX analysis. To study variations on elementary level of NSP, EDX analysis was conducted before and after removal of halosulfuron methyl ${ }^{38}$. It can be demonstrated from the Fig. 1a that NSP consists of $\mathrm{Cu}, \mathrm{Ca}, \mathrm{K}, \mathrm{Cl}$, $\mathrm{S} \mathrm{Na}, \mathrm{O}$ and $\mathrm{C}$ before removal of Halosulfuron methyl. However, new peaks of $\mathrm{N}, \mathrm{Al}, \mathrm{P}$ and $\mathrm{Si}$ were appeared which indicates the variation in the elemental composition after removal of halosulfuron methyl as illustrated in Fig. 1b. Furthermore, the presence of the peak due to nitrogen after removal study proved that halosulfuron methyl was removed significantly because nitrogen atom is a part of halosulfuron methyl molecule.

SEM analysis. To assess any modification in surface morphology of NSP, SEM analysis was performed prior to and subsequent to halosulfuron methyl removal study. It is obvious from Fig. 1c that the surface of NSP is relatively smooth before removal of halosulfuron methyl but significant changes were observed after removal of halosulfuron methyl as illustrated in Fig. 1d and surface of NSP after removal of halosulfuron methyl became somewhat rough and irregular which indicates the removal of Halosulfuron methyl ${ }^{39}$.

Surface analysis. Literature survey revealed that sorption ability of biomass is significantly altered by surface area and pore volume ${ }^{40}$. Hence, data of surface analysis were calculated using $\mathrm{N}_{2}$-adsorption isotherm prior to and subsequent to removal of halosulfuron methyl onto NSP. The results of surface analysis before and after biosorption of halosulfuron methyl are shown in Fig. 2a,b while the data is listed in Table 1. These outcomes demonstrate that surface area of NSP was greater before removal of halosulfuron methyl but was decreased after removal halosulfuron methyl which substantiates the process of removal of halosulfuron methyl from aqueous medium.

Point of zero charge ( $p H z p c$ ). Sorption mechanism can be easily recognized by knowing the magnitude of $\mathrm{pHzpc}$ of biomass ${ }^{41}$. The point of zero charge is the $\mathrm{pH}$ at which the surface of biomass has zero electrical 


\begin{tabular}{|l|l|l|}
\hline Factor & Prior to removal of halosulfuron methyl & Subsequent to removal of halosulfuron methyl \\
\hline Surface area $\left(\mathrm{m}^{2} \mathrm{~g}^{-1}\right)$ & 13.850 & 6.619 \\
\hline Pore volume $(\AA)$ & 0.005 & 0.001 \\
\hline Pore radius $\left(\mathrm{cc}^{-1}\right)$ & 15.035 & 15.008 \\
\hline
\end{tabular}

Table 1. Surface analysis of NSP using $\mathrm{N}_{2}$-adsorption isotherm.

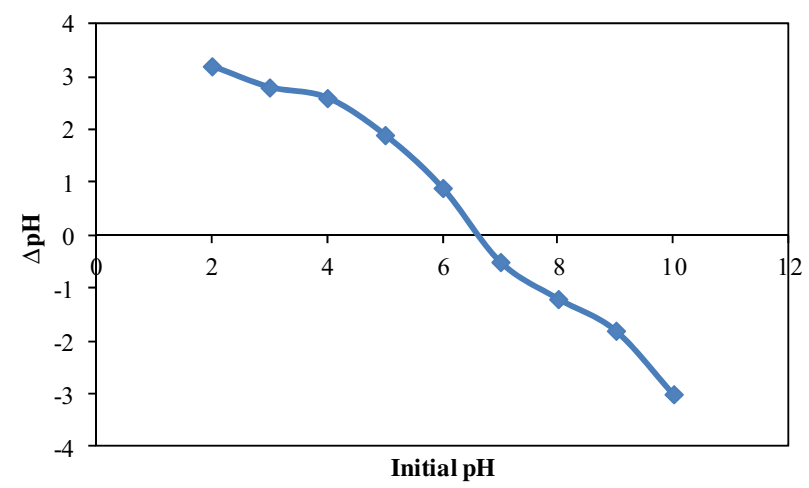

Figure 3. Point of zero charge of NSP.

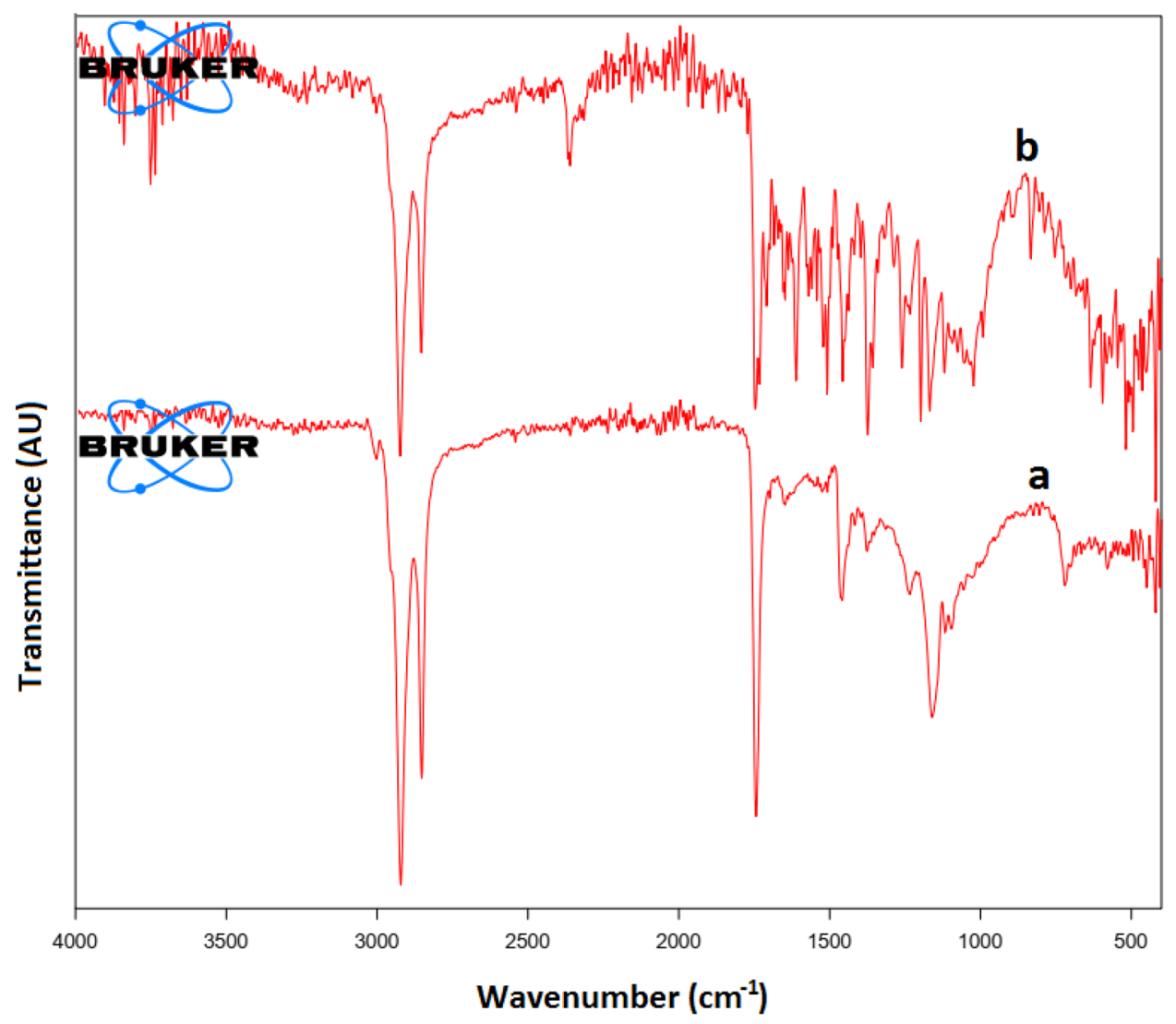

Figure 4. FTIR spectra of NSP before and after biosorption of halosulfuron methyl. 

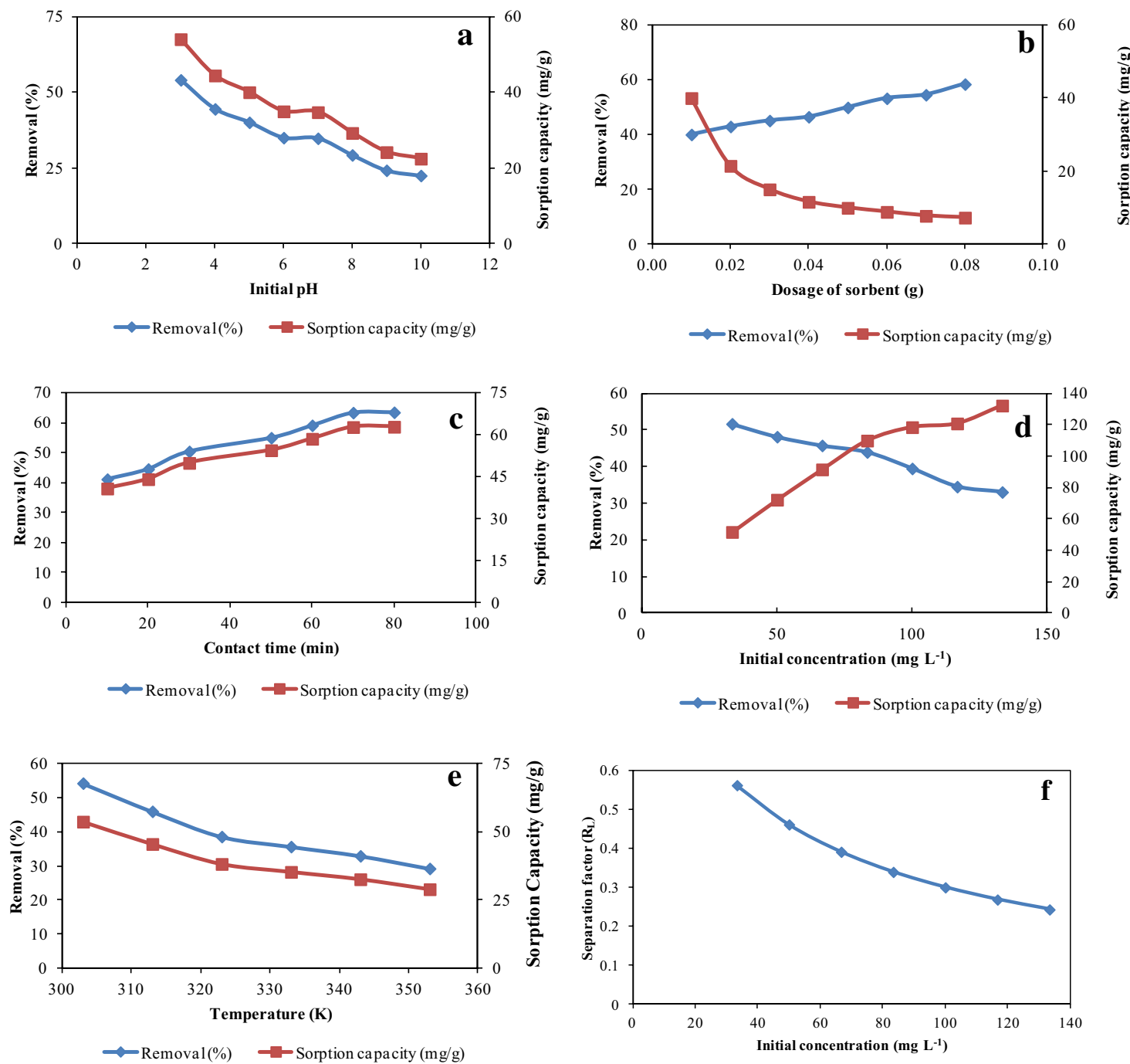

Figure 5. Effect of $\mathrm{pH}$ on removal of halosulfuron methyl employing NSP (a), Effect of sorbent dose on the removal of halosulfuron methyl onto NSP (b), Effect of contact time on the removal of halosulfuron methyl onto NSP (c), Effect of initial concentration of halosulfuron methyl on the removal of halosulfuron methyl onto NSP (d), Effect of temperature on the removal of halosulfuron methyl using NSP (e) Effect of initial concentration of halosulfuron methyl on dimensionless equilibrium parameter $(\mathbf{f})$.

charge density. The surface of biomass has positive charge below pHzpc while the surface becomes negatively charged above the $\mathrm{pHzpc}^{42}$. According to the literature cations removed more favorably at $\mathrm{pH}$ greater than $\mathrm{pHzpc}$ whereas anions removed more favorably at $\mathrm{pH}$ below $\mathrm{pHzpc}^{43}$. The $\mathrm{pHzpc}$ of NSP was assayed using salt addition method ${ }^{44}$. It can be depicted from the Fig. 3 that pHzpc of NSP is 6.5 which suggests that surface of NSP is negatively charged above 6.5 while positively charged below 6.5 . Hence, low $\mathrm{pH}$ is more favorable for the removal of halosulfuron methyl and maximum removal of halosulfuron methyl was obtained from aqueous solution at low $\mathrm{pH}$ as depicted in Fig. 6.

FTIR analysis. FTIR spectrum of the NSP before biosorption of halosulfuron methyl showed distinct peaks at $2921.54,2852.31,1743.72,1458.37$ and $1160.58 \mathrm{~cm}^{-1}$ (Fig. 4a) and each peak could be assigned to particular functional groups as mentioned in the literature. The intense two peaks at 2921.54, 2852.31 might be assigned to $\mathrm{C}-\mathrm{H}$ stretching vibrations of the alkyl group while the intense peak 1743.72 might be attributed to $\mathrm{C}=\mathrm{O}$ stretching vibration of carbonyl group. Similarly the spectral peaks at 1458.37 and 1160.58 represent the C-O stretching vibration of carboxylic acid and $\mathrm{C}-\mathrm{O}-\mathrm{C}$ stretching vibration of ether respectively. After biosorption some new peaks are appeared such as $3854.43,2360.43,1647.73,1610.84,1374.31 \mathrm{~cm}^{-1}$ (Fig. $4 \mathrm{~b}$ ) which indicates the complex nature of halosulfuron methyl pesticide. Similarly, the intensities of some peaks have changed and some peaks have sifted which indicates the biosorption of halosulfuron methyl pesticide.

Effect of $\mathrm{pH}$. Solution $\mathrm{pH}$ serves a vital function in removal of pollutants because it changes the chemistry of sorbent surface and the interaction of sorbent and sorbate molecule ${ }^{45}$. Consequently, the reliance of 


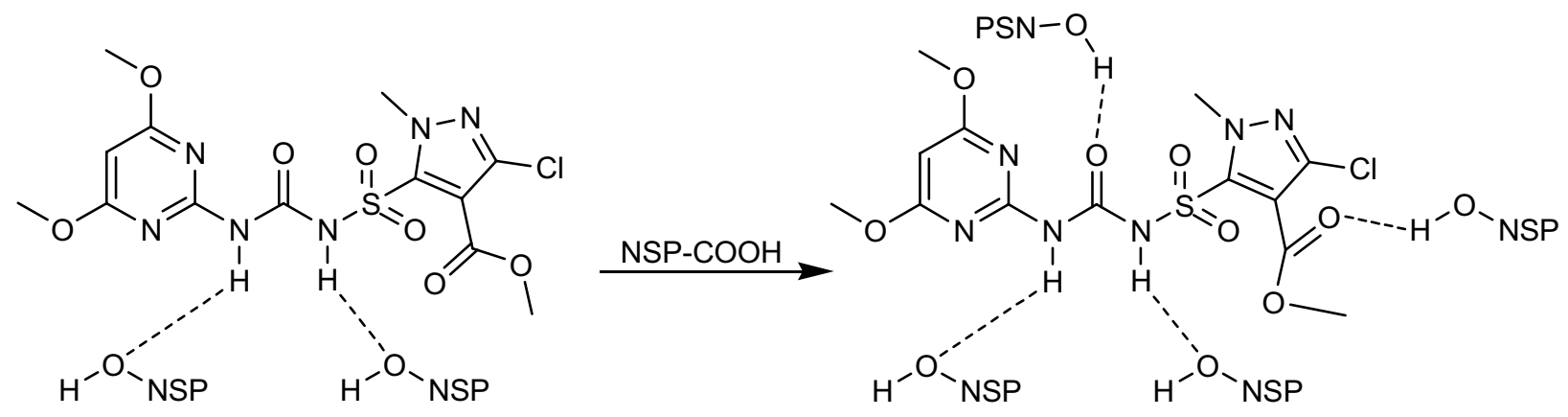

Figure 6. Possible interaction of halosulfuron methyl molecule with NSP.

removal of halosulfuron methyl on initial solution $\mathrm{pH}$ was ascertained by changing $\mathrm{pH}$ in ranging of 3-10 with a particular initial concentration $\left(33.33 \mathrm{mg} \mathrm{L}^{-1}\right)$ of halosulfuron methyl. The change in removal of halosulfuron methyl with respect to $\mathrm{pH}$ is shown in Fig. 5a which depicts that maximum removal of halosulfuron methyl was noted at low $\mathrm{pH}$ but a continuous decrease in the removal was observed after increasing $\mathrm{pH}$ of solution. It may be inferred from this result that favorable $\mathrm{pH}$ to remove halosulfuron methyl is low. The possible interaction between halosulfuron methyl and NSP is given in the equation shown in Fig. 6. At low pH, protonation of the NSP surface occurs which then further interact with halosulfuron methyl molecule through van der Waals forces ${ }^{46}$. As a result, maximum removal of halosulfuron methyl was obtained at low $\mathrm{pH}$ but at high $\mathrm{pH}$ the interaction between halosulfuron methyl and NSP become weak due to which a continuous decrease in removal process was observed.

Effect of sorbent dose. Along with other variables, sorbent dose has also been included in those factors which can influence the removal of pollutants ${ }^{40}$. To check the variation in removal of halosulfuron methyl with respect to dose of NSP, dose of NSP was changed in the range of 0.01-0.08 (gram) with a desirable concentration of halosulfuron methyl. The result is illustrated in Fig. 5b, indicating that removal percentage of halosulfuron methyl was raised with progress in sorbent dose. The surface area increases as the dose of sorbent was increased due to which more sorptive sites are accessible for interaction of sorbate molecules. Consequently, maximal removal of halosulfuron methyl was found at high dose of NSP ${ }^{47}$. However, sorption capacity was found to be decreased continuously with increase in dose of NSP and then the sorption capacity become constant. Such reduction in the sorption capacity with respect to dose of NSP may be ascribed to a relative amount of halosulfuron methyl in solution with regard to sorptive sites on $\mathrm{NSP}^{48}$.

Effect of contact time. Time of contact also serves an essential role in removal study as it identifies time needed for maximum interaction of sorbate molecules with active sites on sorbent surface ${ }^{49}$. Therefore, the removal of halosulfuron methyl using NSP was studied regarding the impact of contact time by altering time in ranging of 10-80 min with particular concentration of halosulfuron methyl $\left(33.33 \mathrm{mg} \mathrm{L}^{-1}\right)$ and sorbent dose $(0.01 \mathrm{~g})$. The outcome of this factor is depicted in Fig. $5 \mathrm{c}$ which exhibits that percent removal of halosulfuron methyl onto NSP was raised as contact time was increased and within $70 \mathrm{~min}$, equilibrium was obtained. However, no appreciable variation in the percent removal was noticed after $70 \mathrm{~min}$. Such finding signifies that availability of time for the interaction of halosulfuron methyl and binding sites increases with progress in time of contact. Consequently, percent removal of halosulfuron methyl was raised with contact time but after establishment of equilibrium no prominent change in the percent removal was observed. Therefore, further removal experiments were performed at $70 \mathrm{~min}$.

Effect of initial concentration of halosulfuron methyl. Rate of sorption is strongly altered by initial concentration of sorbate ${ }^{39}$. Keeping the importance of the initial concentration of halosulfuron methyl in mind, concentration of halosulfuron methyl was changed in the range of $33.33-133.33\left(\mathrm{mg} \mathrm{L}^{-1}\right)$ whilst maintaining unchanged other variables. The consequence of this variable is shown in Fig. 5d which illustrates that percent removal of halosulfuron methyl onto NSP decreases constantly with raise in initial concentration of halosulfuron methyl. Literature survey demonstrates that initial concentration supplies a driving force for controlling resistance of mass transfer of sorbate molecules between aqueous phase and solid phase however such phenomenon is restricted at higher initial concentration perhaps because of occupation of accessible sorptive sites on sorbent ${ }^{50}$. Therefore, percent removal of halosulfuron methyl onto NSP was high at low initial concentration but was decreased continuously at higher initial concentration. Conversely, sorption capacity of NSP for halosulfuron methyl was increased with each rise in initial concentration. This performance was assigned to the fact that ratio of halosulfuron methyl molecules to binding sites of NSP was small at low initial concentration that results to small sorption capacity ${ }^{51}$. Nevertheless, as initial concentration was raised, this ratio was also increased and resultantly sorption capacity was found maximum at higher initial concentration.

Effect of temperature. It has been cited in literature that sorption is initiated at interface of two phases through thermodynamics which relies on randomness of sorbate at surface of sorbent ${ }^{40}$. Consequently, change 


\begin{tabular}{|c|c|c|c|c|}
\hline Model & Non linear & Linear & Parameter & Plot \\
\hline Pseudo first order & $q_{t}=q_{e}\left(1-e^{-k_{1} t}\right)$ & $\log \left[q_{e}-q_{t}\right]=\log q_{e}-\left[\frac{k_{1}}{2.303}\right] t$ & $\begin{array}{l}\mathrm{k}_{\mathrm{l}}\left(\mathrm{min}^{-1}\right) \text { : rate constant for pseudo } \\
\text { first order } \\
\mathrm{q}_{\mathrm{e}}\left(\mathrm{mg} \mathrm{g}^{-1}\right) \text { : sorption capacity at } \\
\text { equilibrium } \\
\mathrm{q}_{\mathrm{t}}\left(\mathrm{mg} \mathrm{g}^{-1}\right) \text { : Sorption capacity at } \\
\text { time " } \mathrm{t}^{\text {" }}\end{array}$ & $\log \left[q_{e}-q_{t}\right]$ vs $t$ \\
\hline Pseudo second order & $q_{t}=\frac{\left(k_{2} q_{e}^{2} \cdot t\right)}{\left(1+k_{2} q_{e}^{2} \cdot t\right)}$ & $\frac{t}{q_{t}}=\frac{1}{k_{2}\left(q_{e}\right)^{2}}+\frac{1}{q_{e}}(t)$ & $\begin{array}{l}\mathrm{k}_{2}\left(\mathrm{~g} \mathrm{mg}^{-1} \mathrm{~min}^{-1}\right) \text { : rate constant for } \\
\text { pseudo first order }\end{array}$ & $\frac{t}{q_{t}}$ vs $t$ \\
\hline Elovich & $q_{t}=\beta \ln (\alpha \beta t)$ & $q_{t}=\frac{1}{\beta} \ln [\alpha \beta]+\frac{1}{\beta} \ln [t]$ & $\begin{array}{l}\alpha\left(\mathrm{mgg}^{-1} \mathrm{~min}^{-1}\right) \text { rate of sorption } \\
\text { process } \\
\beta\left(\mathrm{gmg}^{-1}\right): \text { activation energy for } \\
\text { chemical sorption process }\end{array}$ & $q_{t} \mathrm{vs} \ln [t]$ \\
\hline Intraparticle diffusion & $q_{t}=K_{i p} t^{0.5}$ & $q_{t}=K_{i p} t^{0.5}+I$ & $\begin{array}{l}\mathrm{K}_{\mathrm{ip}}\left(\mathrm{mg} \mathrm{g}^{-1} \mathrm{~min}^{0.5}\right) \text { : constant for } \\
\text { intraparticle diffusion } \\
\mathrm{I}\left(\mathrm{mg} \mathrm{g}^{-1}\right) \text { : constant related with } \\
\text { thickness of boundary layer }\end{array}$ & $q_{t} \mathrm{vs} t^{0.5}$ \\
\hline Liquid film diffusion & - & $\ln [1-F]=-k_{f d}(t)$ & $\begin{array}{l}\mathrm{F}:\left(\mathrm{q}_{\mathrm{f}} / \mathrm{q}_{\mathrm{e}}\right) \text { : fractional attainment of } \\
\text { equilibrium } \\
\mathrm{k}_{\mathrm{fl}}\left(\min ^{-1}\right) \text { : rate constant of liquid } \\
\text { film diffusion }\end{array}$ & $-\ln [1-F]$ vs $t$ \\
\hline
\end{tabular}

Table 2. Sorption kinetics models and their linear and non-linear forms with corresponding plots.

\begin{tabular}{|c|c|c|c|}
\hline Model & Parameter & Linear & Non linear \\
\hline & $\mathrm{q}_{\mathrm{e}}$, experimental $\left(\mathrm{mg} \mathrm{g}^{-1}\right)$ & 62.88 & 62.88 \\
\hline \multirow{4}{*}{ Pseudo first order } & $\mathrm{q}_{\mathrm{e}}, \mathrm{cal}\left(\mathrm{mg} \mathrm{g}^{-1}\right)$ & 83.29 & 83.255 \\
\hline & $\mathrm{K}_{1}\left(\min ^{-1}\right)$ & 0.069 & 0.021 \\
\hline & $\chi^{2}$ & - & 50.205 \\
\hline & $\mathrm{R}^{2}$ & 0.6726 & 1.000 \\
\hline \multirow{4}{*}{ Pseudo second order } & $\mathrm{q}_{\mathrm{e}}, \mathrm{cal}\left(\mathrm{mg} \mathrm{g}^{-1}\right)$ & 70.422 & 54.859 \\
\hline & $\mathrm{K}_{2}\left(\mathrm{~g} \mathrm{mg}^{-1} \mathrm{~min}^{-1}\right)$ & 0.00131 & 0.050 \\
\hline & $\chi^{2}$ & - & 7.694 \\
\hline & $\mathrm{R}^{2}$ & 0.9908 & 1.000 \\
\hline \multirow{4}{*}{ Elovich } & $\alpha\left(\mathrm{mgg}^{-1} \min ^{-1}\right)$ & 33.953 & 33.958 \\
\hline & $\beta\left(\mathrm{g} \mathrm{mg}^{-1}\right)$ & 0.0884 & 5.911 \\
\hline & $\chi^{2}$ & - & 2.361 \\
\hline & $\mathrm{R}^{2}$ & 0.9526 & 1.000 \\
\hline \multirow{4}{*}{ Intraparticle diffusion } & $\mathrm{K}_{\mathrm{ip}}$ & 4.064 & 3.875 \\
\hline & I & 27.085 & 27.085 \\
\hline & $\chi^{2}$ & - & 0.353 \\
\hline & $\mathrm{R}^{2}$ & 0.9842 & 1.000 \\
\hline \multirow{3}{*}{ Liquid film diffusion } & $\mathrm{K}_{\mathrm{fd}}\left(\min ^{-1}\right)$ & 0.0691 & - \\
\hline & Intercept & -0.2811 & - \\
\hline & $\mathrm{R}^{2}$ & 0.6726 & - \\
\hline
\end{tabular}

Table 3. Kinetic parameters for the removal of halosulfuron methyl using NSP.

in temperature has significant task in designating randomness at the interface of two phases. Therefore, temperature was altered from 303 to $353 \mathrm{~K}$ in order to assess its impact on the removal of halosulfuron methyl onto NSP while other factors were kept unchanged. Figure 5e illustrates the variation of halosulfuron methyl removal with temperature which demonstrates that removal of halosulfuron methyl was constantly declined with rise in temperature. Such result indicates that high temperature did not favor the removal of halosulfuron methyl from aqueous media. Hence, it may be suggested that active sites on NSP involving in removal process were decreased with rise in temperature. Subsequently, removal of halosulfuron methyl was declined at high temperature. Therefore, further removal study of halosulfuron methyl was performed at room temperature.

Kinetics study. Experimental data were examined using kinetic models to investigate sorption mechanism and rate controlling step ${ }^{52}$. Moreover, kinetics of the sorption study is required for the determination of sorption velocity ${ }^{53}$. Literature study revealed that a variety of kinetic models were tested to find out mechanism of sorption process but in current study five most commonly used models like pseudo first order, pseudo second order, Elovich, intraparticle and liquid film diffusion models were applied for prediction of kinetics of halosulfuron methyl removal from water media. Chi-square analysis $\left(\chi^{2}\right)$ was used to evaluate the best fitting kinetic model 


\begin{tabular}{|c|c|c|c|c|}
\hline Isotherm & Non linear & Linear & Parameters & Plot \\
\hline Freundlich & $q_{e}=K_{F} C_{e}^{1 / n}$ & $\log \left(q_{e}\right)=\log K_{F}+\frac{1}{n} \log \left(C_{e}\right)$ & $\begin{array}{l}\mathrm{K}_{\mathrm{F}}\left(\mathrm{mg} \mathrm{g}^{-1}\right) \text { : sorption capacity } \\
1 / \mathrm{n}: \text { intensity of sorption } \\
\mathrm{C}_{\mathrm{e}}\left(\mathrm{mg} \mathrm{L}^{-1}\right) \text { : equilibrium concentration } \\
\mathrm{q}_{\mathrm{e}}\left(\mathrm{mgg}^{-1}\right) \text { : sorption capacity }\end{array}$ & $\log \left(q_{e}\right)$ vs $\log \left(C_{e}\right)$ \\
\hline Langmuir & $q_{e}=\frac{Q_{\max } K_{L} C_{e}}{1+K_{L} C_{e}}$ & $\begin{array}{l}\frac{C_{e}}{q_{e}}=\frac{1}{Q_{\max } K_{L}}+\frac{C_{e}}{Q_{\max }} \\
R_{L}=\frac{1}{1+K_{L} C_{o}}\end{array}$ & $\begin{array}{l}\mathrm{Q}_{\max }\left(\mathrm{mg} \mathrm{g}^{-1}\right) \text { : maximum monolayer sorption } \\
\text { capacity } \\
\mathrm{K}_{\mathrm{L}}\left(\mathrm{L} \mathrm{mg}^{-1}\right) \text { : constant related with sorption } \\
\text { energy } \\
\mathrm{R}_{\mathrm{L}}: \text { separation factor } \\
\mathrm{C}_{\mathrm{o}}\left(\mathrm{mg} \mathrm{L}^{-1}\right) \text { : Initial concentration }\end{array}$ & $\frac{C_{e}}{q_{e}}$ vs $C_{e}$ \\
\hline Temkin & $q_{e}=\left(\frac{R T}{b_{T}}\right) \ln K_{T} C_{e}$ & $q_{e}=R T \ln K_{T}+\frac{R T}{b_{T}} \ln C_{e}$ & $\begin{array}{l}\mathrm{b}_{\mathrm{T}}\left(\mathrm{J} \mathrm{mol}^{-1}\right) \text { : constant related with heat of sorp- } \\
\text { tion } \\
\mathrm{K}_{\mathrm{T}}\left(\mathrm{L} \mathrm{g}^{-1}\right) \text { : Temkin isotherm constant }\end{array}$ & $q_{e}$ vs $\ln C_{e}$ \\
\hline $\mathrm{D}-\mathrm{R}$ & $q_{e}=q_{d} \exp \left(-\beta \varepsilon^{2}\right)$ & $\begin{array}{l}\ln q_{e}=\ln q_{d}-\beta \varepsilon^{2} \\
\varepsilon=R \ln \left[1+\frac{1}{C_{e}}\right] \\
E=\frac{1}{\sqrt{2 \beta}}\end{array}$ & $\begin{array}{l}\beta\left(\mathrm{mol}^{2} / \mathrm{kJ}^{2}\right): \text { constant related with free energy } \\
\mathrm{q}_{\mathrm{d}}\left(\mathrm{mg} \mathrm{g}^{-1}\right): \text { maximum sorption capacity } \\
\varepsilon: \text { Polanyi potential } \\
\mathrm{R}\left(\mathrm{Jmol}^{-1} \mathrm{~K}^{-1}\right) \text { : gas constant } \\
\mathrm{T}(\mathrm{K}) \text { : temperature } \\
\mathrm{E}\left(\mathrm{kJ} \mathrm{mol}^{-1}\right) \text { : mean sorption energy }\end{array}$ & $\ln q_{e}$ vs $\varepsilon^{2}$ \\
\hline
\end{tabular}

Table 4. Sorption isotherms and their non-linear and linear forms with corresponding plots.

by non-linear regression. The value of $\chi^{2}$ of each model was calculated and listed in Table 3 . The lower value of $\chi^{2}$ suggested the best fitting of the predictive kinetic model.

Pseudo first order. According to pseudo first order there is a linear relationship between rates of coverage of sorptive sites to the vacant sorptive sites ${ }^{54}$. The nonlinear and linear form of this model is given in Table 2 . The rate constant for pseudo first order kinetic, $\mathrm{k}_{1}\left(\mathrm{~min}^{-1}\right)$ and $\mathrm{q}_{\mathrm{e}}$ were computed from slope and intercept by plotting $\log \left(\mathrm{q}_{\mathrm{e}}-\mathrm{q}_{\mathrm{t}}\right)$ against time $(\mathrm{t})$.

Pseudo second order. Such model could be employed for prediction of kinetic performance of sorption occurs through chemisorption as presented by Ho and Mckay ${ }^{55}$. The nonlinear and linear form of this model is given in Table 2. The rate constant for pseudo second, $\mathrm{k}_{2}\left(\mathrm{~g} \mathrm{mg}^{-1} \mathrm{~min}^{-1}\right)$ and $\mathrm{q}_{\mathrm{e}}$ were computed from slope and intercept by plotting $\mathrm{t} / \mathrm{q}_{\mathrm{t}}$ versus time.

Elovich model. According to this model, surfaces of sorbent are energetically heterogamous in nature and sorption occurs through chemisorption ${ }^{53}$. The constant parameters, $\alpha\left(\mathrm{mgg}^{-1} \mathrm{~min}^{-1}\right)$ and $\beta\left(\mathrm{gmg}^{-1}\right)$ are the rate of sorption process and activation energy for chemical sorption process correspondingly. The magnitudes of these two parameters were computed from slope and intercept by potting $q_{t}$ against $\ln (t)$.

Intraparticle diffusion model. Two scientists, namely Weber and Morris presented a model known as intraparticle diffusion which may be generally employed for the investigation of nature of rate controlling step ${ }^{56}$. The rate constant for intraparticle diffusion $\mathrm{K}_{\mathrm{ip}}\left(\mathrm{mg} \mathrm{g}^{-1} \mathrm{~min}^{0.5}\right)$ and I $\left(\mathrm{mg} \mathrm{g}^{-1}\right)$ were executed from the slope and intercept of plot $\mathrm{q}_{\mathrm{t}}$ against $\mathrm{t}^{0.5}$. It has been given in the literature that intraparticle diffusion would be the rate determining step if plot of $q_{t}$ against $t^{0.5}$ is a straight line with zero intercept ${ }^{57}$. However, our results revealed intercept of the line is not zero which indicates that removal of halosulfuron methyl from aqueous solution did not control by intraparticle diffusion model.

Liquid film diffusion model. Surface diffusion plays a vital role in sorption process and to find out whether the sorption occurs through surface diffusion or not, the sorption data was fitted in this model ${ }^{58}$. Literature study suggest that removal of halosulfuron methyl will be determined by liquid film diffusion if graph of $-\ln (1-\mathrm{F})$ versus time has zero intercept ${ }^{18}$. However, our result indicates as shown in Table 2 that intercept of liquid film diffusion model is not zero which suggests that other kinetic models are involved in removal of halosulfuron methyl pesticide.

The rate constants of kinetic models and other kinetic constant factors were computed from their respective linear and non-linear form of kinetic models and listed in Table 3 along with correlation coefficients. An inclusive comparative study of the correlation coefficients $\left(\mathrm{R}^{2}\right)$ of the above five kinetic models indicates that pseudo second order has highest value (0.99) which suggests that removal of halosulfuron methyl may be explained more satisfactorily by pseudo-2nd as compared other kinetic models. Moreover, the nearness of experimental (qe, exp) and calculated adsorption capacity (qe, cal) computed from pseudo second order demonstrating the fitness of model.

Isotherm study. An isotherm is the graphical description of the relation between the quantity sorbed per unit mass of sorbent and the quantity of sorbate in solution at fixed temperature. It provides the information associated with division of sorbate between liquid and solid phases at different equilibrium concentrations ${ }^{59}$. Linear regression models of Freundlich, Langmuir, Temkin and D-R are used to investigate the best fitting iso- 


\begin{tabular}{|l|l|l|l|}
\hline Model & Parameter & Linear & Non linear \\
\hline \multirow{4}{*}{ Freundlich } & $\mathrm{K}_{\mathrm{F}}\left(\mathrm{mg} \mathrm{g}^{-1}\right)$ & 12.416 & 12.416 \\
\cline { 2 - 4 } & $1 / \mathrm{n}$ & 0.5406 & 0.550 \\
\cline { 2 - 4 } & $\mathrm{R}^{2}$ & 0.9564 & 1.000 \\
\hline \multirow{4}{*}{ Temkingmuir } & $\mathrm{K}_{\mathrm{L}}$ & 0.0233 & 0.024 \\
\cline { 2 - 4 } & $\mathrm{Q}_{\max }\left(\mathrm{mg} \mathrm{g}^{-1}\right)$ & 200 & 200 \\
\cline { 2 - 4 } & $\mathrm{R}^{2}$ & 0.9819 & 1.000 \\
\hline \multirow{5}{*}{$\mathrm{D}-\mathrm{R}$} & $\mathrm{K}_{\mathrm{T}}$ & 0.9688 & -0.631 \\
\cline { 2 - 4 } & $\mathrm{b}_{\mathrm{T}}$ & 52.446 & 52.566 \\
\cline { 2 - 4 } & $\mathrm{R}^{2}$ & 0.9804 & 1.000 \\
\hline & $\mathrm{q}_{\mathrm{d}}(\mathrm{mg} \mathrm{g}$ & 122.547 & 122.547 \\
\cline { 2 - 4 } & $\mathrm{B}$ & $4 \times 10^{-5}$ & $2.01 \times 10^{-5}$ \\
\cline { 2 - 4 } & $\mathrm{E}\left(\mathrm{kJ} / \mathrm{mol}^{-1}\right)$ & 0.111 & - \\
\cline { 2 - 4 } & $\mathrm{R}^{2}$ & 0.9206 & 1.00 \\
\hline
\end{tabular}

Table 5. Isotherm constants for the removal of halosulfuron methyl using NSP.

therm as shown in Table 4 and isotherm parameters were calculated from the slopes and intercepts of these models as illustrated in Table 5 .

Freundlich isotherm. This isotherm is an experimental equation and commonly manipulates to characterize multi-layer sorption on heterogeneous surface ${ }^{60}$. The value of $1 / \mathrm{n}$ of the Freundlich isotherm identifies the practicability of isotherms like favorable, unfavorable or irreversible if its value is $0<1 / \mathrm{n}<1,1 / \mathrm{n}>1$ or $1 / \mathrm{n}=0$ respectively ${ }^{52}$. In the current study, value of $1 / \mathrm{n}$ was found less than one which implies the favorable nature of the removal of halosulfuron methyl.

Langmuir isotherm. This isotherm signifies that process of sorption occurs in such a way that monolayer formed on a surface carrying constant number of vacant sites energetically identical to each other. The sorption energy is fixed and independent of the degree of saturation of the active site on sorbent ${ }^{61}$. The $\mathrm{K}_{\mathrm{L}}$ is one of significant Langmuir constant which may be utilized for the evaluation of separation factor $\left(\mathrm{R}_{\mathrm{L}}\right)$ which demonstrates favorability of sorption process. This parameter signifies mechanism of sorption process whether it should be favorable $\left(0<R_{L}<1\right)$, unfavorable $\left(R_{L}>1\right)$, linear $\left(R_{L}=1\right)$ or irreversible $\left(R_{L}=0\right)$. However, the current investigation indicates that magnitudes of $\mathrm{R}_{\mathrm{L}}$ were found to be in the range of 0.56 to 0.24 as illustrated from the Fig. $4 \mathrm{f}$ which designates that removal of halosulfuron methyl is a favorable process.

Temkin isotherm. This isotherm explains that decreasing of heat of adsorption with respect to temperature is linear instead of logarithmical relationship. Furthermore, there is direct relationship between free energy and surface coverage ${ }^{61}$. The Temkin isotherm explains that decreasing of heat of adsorption with respect to temperature is linear instead of logarithmical relationship. Furthermore, there is direct relationship between free energy and surface coverage ${ }^{61}$. The constant parameters of Temkin isotherm are $\mathrm{b}_{\mathrm{T}}\left(\mathrm{J} \mathrm{mol}^{-1}\right)$ and $\mathrm{K}_{\mathrm{T}}\left(\mathrm{L} \mathrm{g}^{-1}\right)$ which are associated with heat of adsorption and Temkin isotherm constant respectively.

Dubinin-Radushkevich (D-R) isotherm. The Dubinin-Radushkevich (D-R) isotherm is considered as semiempirical equation which demonstrates that sorption occurs through pore filling mechanism. According to this isotherm, sorption process occurs in the form of multilayer by means of van der Waals which may be applied for sorption taking place through physically ${ }^{62}$. The constant parameters of this isotherm are $\beta\left(\mathrm{mol}^{2} / \mathrm{kJ}^{2}\right)$ and $\mathrm{q}_{\mathrm{d}}$ $\left(\mathrm{mg} \mathrm{g}^{-1}\right)$ which are associated with free energy and maximum sorption capacity respectively. The $\beta$ is also related with mean sorption energy $(\mathrm{E})\left(\mathrm{kJ} \mathrm{mol}{ }^{-1}\right)$.

The characteristics of sorption may be demonstrated by the values of mean sorption energy. It is recognized that magnitude of $\mathrm{E}$ for physical sorption is $\mathrm{E}<8\left(\mathrm{~kJ} \mathrm{~mol}^{-1}\right)$ while for a chemical sorption its magnitude is $\mathrm{E}>16$ $\left(\mathrm{kJ} \mathrm{mol}^{-1}\right)$. In the current research work magnitude of mean free energy was found to be $0.111 \mathrm{~kJ} \mathrm{~mol}^{-1}$, which exhibits that removal of halosulfuron methyl from aqueous medium is primarily physical sorption.

The non-linear isotherm parameters and correlation coefficient were calculated using Solver add-in with Microsoft Excel program. The isotherm parameters obtained from these nonlinear equation are given in Table 5 which shown no prominent changes in the conversion of non-linear forms to their linear ones.

A thorough assessment of the correlation coefficients suggest that removal data of halosulfuron methyl was well fitted with Langmuir isotherm due to highest $\mathrm{R}^{2}$ value as compared to other isotherms. This result implied that a monolayer of halosulfuron methyl molecules is formed on the surface of NSP during sorption process. Maximum sorption capacity was computed from Langmuir isotherm and was found to be $200 \mathrm{mg} \mathrm{g}^{-1}$. This comparatively high sorption capacity reveals a strong interaction between halosulfuron methyl molecules and NSP.

Thermodynamic study. Thermodynamic study was accomplished to probe the feasibility, spontaneity and mechanism of the removal of halosulfuron methyl onto NSP from aqueous media by using thermodynamic 


\begin{tabular}{|c|c|c|c|}
\hline Temperature (K) & $\Delta \mathrm{G}^{\circ}\left(\mathrm{kJ} \mathrm{mol}^{-1}\right)$ & $\Delta \mathrm{H}^{\circ}\left(\mathrm{kJ} \mathrm{mol}^{-1}\right)$ & $\Delta \mathrm{S}^{\circ}\left(\mathrm{J} \mathrm{mol}^{-1} \mathrm{~K}^{-1}\right)$ \\
\hline 303 & -3.208 & \multirow{6}{*}{-18.083} & \multirow{6}{*}{-0.0497} \\
\hline 313 & -2.449 & & \\
\hline 323 & -1.710 & & \\
\hline 333 & -1.415 & & \\
\hline 343 & -1.112 & & \\
\hline 353 & -0.637 & & \\
\hline
\end{tabular}

Table 6. Thermodynamic parameters for the removal of halosulfuron methyl onto NSP.

\begin{tabular}{|l|l|}
\hline Concentration of $\mathrm{NaOH}(\mathrm{M})$ & Recovery of halosulfuron methyl (\%) \\
\hline 1.0 & 40.56 \\
\hline 0.1 & 32.75 \\
\hline 0.01 & 20.25 \\
\hline
\end{tabular}

Table 7. Regeneration of halosulfuron methyl loaded-NSP.

parameters like enthalpy $\left(\Delta \mathrm{H}^{\circ}\right)$, entropy $\left(\Delta \mathrm{S}^{\circ}\right)$ and free energy $\left(\Delta \mathrm{G}^{\circ}\right)^{63}$. These were determined using the following formulae:

$$
\begin{gathered}
K_{D}=\frac{q_{e}}{C_{e}} \\
\Delta G^{\circ}=-R T \ln K_{D} \\
\ln K_{D}=\frac{\Delta S^{\circ}}{R}-\frac{\Delta H^{\circ}}{R T}
\end{gathered}
$$

In these equations $\mathrm{K}_{\mathrm{D}}$, $\mathrm{R}$ and $\mathrm{T}$ express distribution coefficient, gas constant and the temperature respectively. The magnitudes of $\Delta \mathrm{H}^{\circ}$ and $\Delta S^{\circ}$ were evaluated by plotting $\ln \mathrm{K}_{\mathrm{D}}$ versus $1 / \mathrm{T}$ and listed in Table 6 . The negative $\Delta \mathrm{G}^{\circ}$ reveals that removal of halosulfuron methyl from aqueous media using NSP is a spontaneous process ${ }^{64}$. It has also been depicted from the table that value of $\Delta \mathrm{H}^{\circ}$ is negative suggests that removal of halosulfuron methyl is exothermic in nature. Likewise, the negative $\Delta \mathrm{H}^{\circ}$ proposed that removal of halosulfuron methyl onto NSP is physical adsorption ${ }^{65}$. The parameter $\Delta S^{\circ}$ was found negative, which suggests a decrease in randomness at solid solution interface during the occupation of halosulfuron methyl molecules on the binding sites of NSP ${ }^{66}$.

Regeneration study. The regeneration study indicates only $20 \%$ of the adsorbed halosulfuron methyl was recovered from the loaded-NSP as shown in Table 7. However, the recovery efficiency was increased as the concentration of $\mathrm{NaOH}$ was increased and maximum recovery of halosulfuron methyl from the loaded-NSP was observed with $1.0 \mathrm{M} \mathrm{NaOH}$.

\section{Conclusion}

The purpose of the current study was to evaluate the potential of neem seed powder as an efficient biosorbent for the removal of halosulfuron methyl from water solution. The EDX, SEM, surface analysis indicate the interaction of halosulfuron methyl with the surface of neem seed powder. The $\mathrm{pH}$ study demonstrates that removal of halosulfuron methyl onto NSP is $\mathrm{pH}$ dependent and maximum removal was observed in acidic medium. Point of zero charge of NSP was found to be 6.5 which further confirm the suitable $\mathrm{pH}$ for the removal of halosulfuron methyl. Kinetic study demonstrated that removal of halosulfuron methyl onto NSP well describe by pseudo second order model. The isotherms results imply that Langmuir is the best isotherm model to explain the removal of halosulfuron methyl and maximum monolayer sorption capacity was found be $200 \mathrm{mg} \mathrm{g}^{-1}$. Thermodynamic parameters suggested the exothermic and spontaneity nature of the removal of halosulfuron methyl from aqueous solution. Overall outcome implies that neem seed power is an effective, inexpensive and ecofriendly sorbent for the treatment of wastewater.

Received: 9 August 2020; Accepted: 8 April 2021

Published online: 11 May 2021

\section{References}

1. Plakas, V. K. \& Anastasios, J. K. Removal of pesticide from water by NF and RO membranes-A review. Desalination 287, 255-265 (2012).

2. Cara, I. G. \& Jitareanu, G. Application of low-cost adsorbents for pesticide removal. Bull. USAMV Ser Agric. 72, 37-44 (2015). 
3. Chand, M., Singh, S., Bir, D., Singh, N. \& Kumar, V. Halosulfuron methyl: A new post emergence herbicide in India for effective control of Cyperus rotundus in sugarcane and its residual effects on the succeeding crops. Sugar Tech. 16, 67-74 (2014).

4. Zhang, H. \& Zhao, L. Influence of sublethal doses of acetamiprid and halosulfuron-methyl on metabolites of zebra fish (Brachydanio rerio). Aquat. Toxicol. 191, 85-94 (2017).

5. Bhatnagar, A., Sillanpaa, M. \& Witek-Krowiak, A. Agricultural waste peels as versatile biomass for water purification-a review. Chem. Eng. J. 270, 244-271 (2015).

6. Mishra, V. Biosorption of zinc ion: A deep comprehension. Appl. Water Sci. 4, 311-332 (2014).

7. Nguyen, T. A. H. et al. Applicability of agricultural waste and by-products for adsorptive removal of heavy metals from wastewater. Bioresour. Technol. 148, 574-585 (2013).

8. Abigail, M. E. A., Samuel, M. S. \& Chidambaram, R. Application of rice husk nanosorbents containing 2,4-dichlorophenoxyacetic acid herbicide to control weeds and reduce leaching from soil. J. Taiwan Inst. Chem. Eng. 63, 318-326 (2016).

9. Samuel, M. S. In Vitro evaluation of the antibacterial activity of Mucuna pruriens leaf and callus extracts. Afr. J. Microbiol. Res. 7, 3101-3111 (2013).

10. Datta, S., Veena, R., Samuel, M. S. \& Selvarajan, E. Immobilization of laccases and applications for the detection and remediation of pollutants: A review. Environ. Chem. Lett. https://doi.org/10.1007/s10311-020-01081-y (2020).

11. Thevannan, A., Mungroo, R. \& Niu, C. H. Biosorption of nickel with barley straw. Bioresour. Technol. 101, 1776-1780 (2010).

12. Datta, S., Rajnish, K. N., Samuel, M. S., Pugazlendhi, A. \& Selvarajan, E. Metagenomic applications in microbial diversity, bioremediation, pollution monitoring, enzyme and drug discovery. A review. Environ. Chem. Lett. 18, 1229-1241 (2020).

13. Samuel, M. S. et al. Green synthesis of cobalt-oxide nanoparticle using jumbo Muscadine (Vitis rotundifolia): Characterization and photo-catalytic activity of acid Blue-74. J. Photochem. Photobiol. B Biol. 211, 112011 (2020).

14. Samuel, M. S. et al. Immobilization of $\mathrm{Cu}_{3}(\mathrm{btc})_{2}$ on graphene oxide-chitosan hybrid composite for the adsorption and photocatalytic degradation of methylene blue. J. Photochem. Photobiol. B Biol. 204, 111809 (2020).

15. Vijayaraghavan, K. \& Balasubramanian, R. Is biosorption suitable for decontamination of metal-bearing wastewaters? A critical review on the state-of-the-art of biosorption processes and future directions. J. Environ. Manag. 160, 283-296 (2015).

16. Fomina, M. \& Gadd, G. M. Biosorption: Current perspectives on concept, definition and application. Bioresour. Technol. 160, 3-14 (2014).

17. Hlihor, R. M. et al. Experimental analysis and mathematical prediction of Cd(II) removal by biosorption using support vector machines and genetic algorithms. New Biotechnol. 32, 358-368 (2015).

18. Zhou, K., Yang, Z., Liu, Y. \& Kong, X. Kinetics and equilibrium studies on biosorption of $\mathrm{Pb}$ (II) from aqueous solution by a novel biosorbent: Cyclosorus interruptus. J. Environ. Chem. Eng. 3, 2219-2228 (2015).

19. Wang, G. et al. Removal of $\mathrm{Pb}$ (II) from aqueous solutions by Phytolacca amcricana L. biomass as a low cost biosorbent. Arab. J. Chem. 11(1), 99-110 (2018).

20. López-Mesas, M., Navarrete, E. R., Carrillo, F. \& Palet, C. Bioseparation of $\mathrm{Pb}(\mathrm{II})$ and $\mathrm{Cd}(\mathrm{II})$ from aqueous solution using cork waste biomass. Modeling and optimization of the parameters of the biosorption step. Chem. Eng. J. 174, 9-17 (2011).

21. Moyo, M., Guyo, U., Mawenyiyo, G., Zinyama, N. P. \& Nyamunda, B. C. Marula seed husk (Sclerocarya birrea) biomass as a low cost biosorbent for removal of $\mathrm{Pb}(\mathrm{II})$ and $\mathrm{Cu}$ (II) from aqueous solution. J. Ind. Eng. Chem. 27, 126-132 (2015).

22. Ronda, A., Calero, M., Blázquez, G., Pérez, A. \& Martín-Lara, M. A. Optimization of the use of a biosorbent to remove heavy metals: Regeneration and reuse of exhausted biosorbent. J. Taiwan Inst. Chem. Eng. 51, 109-118 (2015).

23. Guyo, U., Mhonyera, J. \& Moyo, M. $\mathrm{Pb}$ (II) adsorption from aqueous solutions by raw and treated biomass of maize stover-A comparative study. Process Saf. Environ. Prot. 93, 192-200 (2015).

24. Hafshejani, L. D. et al. Removal of zinc and lead from aqueous solution by nanostructured cedar leaf ash as biosorbent. J. Mol. Liq. 211, 448-456 (2015).

25. Tasar, S., Kaya, F. \& Ozer, A. Biosorption of lead(II) ions from aqueous solution by peanut shells: Equilibrium, thermodynamic and kinetic studies. J. Environ. Chem. Eng. 2, 1018-1026 (2014).

26. Alzohairy, M. A. Therapeutics role of Azadirachta indica (neem) and their active constituents in diseases prevention and treatment. Evid. Based Complement. Alternat. Med. 2016, 1-11 (2016).

27. Bharali, R. K. \& Bhattacharyya, K. G. Biosorption of fluoride on neem (Azadirachta indica) leaf powder. J. Environ. Chem. Eng. 3, 662-669 (2015).

28. Sharma, A. \& Bhattacharyya, K. G. Adsorption of chromium (VI) on Azadirachta indica (neem) leaf powder. Adsorption 10, $327-338(2004)$.

29. Majithiya, D., Yadav, A. \& Tawde, S. Comparative study of Azadirachta indica (neem) leaf powder and activated charcoal as an adsorbent for removal of chromium from an aqueous solution. J. Environ. Sci. Sustain. 1, 21-27 (2013).

30. Kovo, A. S., Olu, S. C. \& Gwatana, E. S. Adsorption of chromium (IV) by a low cost adsorbent prepared from neem leaves. Iran. J. Energy Environ. 5, 277-286 (2014).

31. Pandhare, G., Trivedi, N., Kanse, N. \& Dawande, S. D. Synthesis of low cost adsorbent from Azadirachta indica (neem) leaf powder. Int. J. Adv. Eng. Res. Stud. 3, 29-31 (2013).

32. Ibrahim, M. B. \& Sani, S. Neem (Azadirachta indica) leaves for removal of organic pollutants. J. Geosci. Environ. Prot. 3, 1-9 (2015).

33. Kenneth, A. et al. Removal of Microbes from Hospital Wastewater Using Neem Husk and Cake Activated Carbon. Mod. Chem. Appl. 3, 1-3 (2015)

34. Islamuddin, Gautam, R. K., Siddique, N. F. \& More, N. Azadirachta indica (Neem) leaf powder used as a natural adsorbent for the removal of chromium Cr (VI) from an aqueous solutions. Int. Res. J. Eng. Technol. 3, 2234-2239 (2016).

35. Swathy, P. S., Swathy, M. R. \& Anitha, K. Defluoridation of water using neem (Azadirachta indica) leaf as adsorbent. Int. J. Adv. Res. Innov. Ideas Educ. 3, 483-492 (2017).

36. Venkateswarlu, P., Ratnam, M. V., Rao, D. S. \& Rao, M. V. Removal of chromium from an aqueous solution using Azadirachta indica (neem) leaf powder as an adsorbent. Int. J. Phys. Sci. 2, 188-195 (2007).

37. Malik, R., Lata, S. \& Singhal, S. Neem leaf utilization for copper and zinc ions removal from aqueous solution. Int. J. Sci. Res. 3, 695-705 (2014).

38. Mishra, A., Tripathi, B. P. \& Rai, A. K. Biosorption of $\mathrm{Cr}(\mathrm{VI})$ and $\mathrm{Ni}(\mathrm{ll})$ onto Hydrilla verticillata dried biomass. Ecol. Eng. 73, 713-723 (2014).

39. Long, J. et al. Performance and mechanism of biosorption of nickel(ll) from aqueous solution by nonliving Streptomyces roseorubens SY. Colloids Surf. A Physicochem. Eng. Asp. 548, 125-133 (2018).

40. Haq, A. U. et al. Removal of butachlor from aqueous solution using cantaloupe seed shell powder: Kinetic, equilibrium and thermodynamic studies. Int. J. Environ. Sci. Technol. 16, 6029-6042 (2019).

41. Tyagi, U. \& Khandegar, V. Biosorption potential of Vetiveria zizanioides for the removal of chromium(VI) from synthetic wastewater. J. Hazard. Toxic. Radioact. Waste 22, 04018014 (2018).

42. Dallel, R., Kesraoui, A. \& Seffen, M. Biosorption of cationic dye onto "Phragmites australis" fibers; characterization and mechanism. J. Environ. Chem. Eng. 6, 7247-7256 (2018).

43. Haq, A. U. et al. Evaluation of sorption mechanism of $\mathrm{Pb}$ (II) and $\mathrm{Ni}$ (H) onto pea (Pisum sativum) Peels. J. Oleo Sci. 66, 735-743 (2017).

44. Slimani, R. et al. Calcined eggshells as a new biosorbent to remove basic dye from aqueous solutions: Thermodynamics, kinetics, isotherms and error analysis. J. Taiwan Inst. Chem. Eng. 45, 1578-1587 (2014). 
45. Goyal, N., Jain, S. C. \& Banerjee, U. C. Comparative studies on the microbial adsorption of heavy metals. Adv. Environ. Res. 7, $311-319$ (2003).

46. Sanusi, K. A., Sunday, N. S., Hassan, M. S. \& Abdulqadir, T. A. The effect of operational parameters on biosorption of $\mathrm{Cd}^{2+}, \mathrm{Ni}^{2+}$ and $\mathrm{Cr}^{6+}$ using Glycine max pod (Soya Bean). Environ. Risk Assess Remediat. 2, 26-34 (2018).

47. Razmovski, K. \& Sciban, M. The kinetics of copper (II) adsorption from water by some natural materials. J. Environ. Prot. Ecol. 4, 728-732 (2003).

48. Choi, M. \& Jang, J. Heavy metal ion adsorption onto polypyrrole-impregnated porous carbon. J. Colloid Interface Sci. 325, 287-289 (2008).

49. Amuda, O. S., Giwa, A. A. \& Bello, L. A. Removal heavy metals from industrial wastewater using modified activated coconut shell carbon. Biochem. Eng. J. 36, 174-181 (2007).

50. Baltazar, M. D. P. G. et al. Copper biosorption by Rhodococcus erythropolis isolated from the Sossego Mine-PA-Brazil. J. Mater. Res. Technol. 8, 475-483 (2019).

51. Sedlakova-Kadukova, J., Kopcakova, A., Gresakova, L., Godany, A. \& Pristas, P. Bioaccumulation and biosorption of zinc by a novel Streptomyces Kll strain isolated from highly alkaline aluminium brown mud disposal site. Ecotoxicol. Environ. Saf. 167, 204-211 (2019).

52. Pradhan, D., Sukla, L. B., Mishra, B. B. \& Devi, N. Biosorption for removal of hexavalent chromium using microalgae Scenedesmns sp. J. Clean. Prod. 209, 617-629 (2019).

53. Peng, S. et al. Biosorption of copper, zinc, cadmium and chromium ions from aqueous solution by natural foxtail millet shell. Ecotoxicol. Environ. Saf. 165, 61-69 (2018).

54. Vishana, I., Saha, B., Sivaprakasam, S. \& Kalamdhad, A. Evaluation of Cd(II) biosorption in aqueous solution by using lyophilized biomass of novel bacterial strain Bacillus badius AK: Biosorption kinetics, thermodynamics and mechanism. Environ. Technol. Innov. 14, 100323 (2019).

55. Ghasemi, M. et al. Kinetic and equilibrium study of $\mathrm{Ni}(\mathrm{II})$ sorption from aqueous ssolutions onto Peganum harmala-L. Int. J. Environ. Sci. Technol. 11, 1835-1844 (2014).

56. Mathew, B. B. \& Krishnamurthy, N. B. Screening and identification of bacteria isolated from industrial area groundwater to study lead sorption; Kinetics and statistical optimization of biosorption parameters. Groundwater Sustain. Dev. 7, 313-327 (2018).

57. Gupta, S., Sharma, S. K. \& Kuma, A. Biosorption of Ni(II) ions from aqueous solution using modified Aloe barbadensis Miller leaf powder. Water Sci. Eng. 12, 27-36 (2019).

58. Ofomaia, A. E. Intraparticle diffusion process for lead(II) biosorption onto mansonia wood sawdust. Bioresour. Technol. 101, 5868-5876 (2010).

59. Samuel, M. S., Shah, S. S., Bhattacharya, J., Subramaniam, K. \& Singh, N. D. P. Adsorption of $\mathrm{Pb}(\mathrm{II})$ from aqueous solution using a magnetic chitosan/graphene oxide composite and its toxicity studies. Int. J. Biol. Macromol. 115, 1142-1150 (2018).

60. Samuel, M. S., Abigail, M. E. A. \& Ramalingam, C. Biosorption of $\mathrm{Cr}(\mathrm{VI})$ by Ceratocystis paradoxa MSR2 using isotherm modelling, kinetic study and optimization of batch parameters using response surface methodology. PLoS ONE 10(3), e0118999. https:// doi.org/10.1371/journal.pone.0118999 (2015).

61. Samuel, M. S., Abigail, M. E. A. \& Ramalingam, C. Isotherm modelling, kinetic study and optimization of batch parameters using response surface methodology for effective removal of $\mathrm{Cr}(\mathrm{VI})$ using fungal biomass. PLoS ONE 10(3), e0116884. https://doi.org/ 10.1371/journal.pone.0116884 (2015).

62. Samuel, M. S. et al. Efficient removal of Chromium(VI) from aqueous solution using chitosan grafted graphene oxide (CS-GO) nanocomposite. Int. J. Biol. Macromol. 121, 285-292 (2019).

63. Abigail, M. E. A., Samuel, M. S. \& Ramalingam, C. Hexavalent chromium biosorption studies using Penicillium griseofulvum MSR1 a novel isolate from tannery effluent site: Box-Behnken optimization, equilibrium, kinetics and thermodynamic studies. J. Taiwan Inst. Chem. Eng. 49, 156-164 (2015).

64. Samuel, M. S. et al. A GO-CS@MOF [Zn(BDC)(DMF)] material for the adsorption of chromium(VI) ions from aqueous solution. Compos. B. Eng. 152, 116-125 (2018).

65. Samuel, M. S. et al. Ultrasonic-assisted synthesis of graphene oxide-fungal hyphae: An efficient and reclaimable adsorbent for chromium(VI) removal from aqueous solution. Ultrason. Sonochem. 48, 412-417 (2018).

66. Samuel, M. S. et al. Synthesized $\beta$-cyclodextrin modified graphene oxide ( $\beta$-CD-GO) composite for adsorption of cadmium and their toxicity profile in cervical cancer (HeLa) cell lines. Process Biochem. 93, 28-35 (2020).

\section{Author contributions}

A.u.H. is the corresponding author and wrote the main manuscript. M.S. and M.U. read the manuscript and correct scientifically. T.M. and A.F.Z. explained the mechanism involved in the manuscript. M.N.A. and S.N. corrected the manuscript grammatically. M.K. performed the research work in the laboratory under the supervision of the corresponding author. Finally, all authors reviewed the manuscript again.

\section{Competing interests}

The authors declare no competing interests.

\section{Additional information}

Correspondence and requests for materials should be addressed to A.u.H.

Reprints and permissions information is available at www.nature.com/reprints.

Publisher's note Springer Nature remains neutral with regard to jurisdictional claims in published maps and institutional affiliations.

Open Access This article is licensed under a Creative Commons Attribution 4.0 International License, which permits use, sharing, adaptation, distribution and reproduction in any medium or
format, as long as you give appropriate credit to the original author(s) and the source, provide a link to the Creative Commons licence, and indicate if changes were made. The images or other third party material in this article are included in the article's Creative Commons licence, unless indicated otherwise in a credit line to the material. If material is not included in the article's Creative Commons licence and your intended use is not permitted by statutory regulation or exceeds the permitted use, you will need to obtain permission directly from the copyright holder. To view a copy of this licence, visit http://creativecommons.org/licenses/by/4.0/.

(C) The Author(s) 2021 